\title{
Low-CARbon BuILding Innovation Trends AND Policy Pespectives in Hungary between 2020 AND 2030
}

\begin{abstract}
Csaba Fogarassy ${ }^{1}$, Balint Horvath ${ }^{2}$
${ }^{1}$ Faculty of Economics and Social Sciences, Climate Change Economic Research Centre, Szent István University, 1. Páter Károly Street, Gödöllö, 2100, Hungary

Fogarassy.Csaba@gtk.szie.hu

${ }^{2}$ Faculty of Economics and Social Sciences, Climate Change Economic Research Centre, Szent István University, 1. Páter Károly Street, Gödöllö, 2100, Hungary

horvath@carbonmangement.hu

Abstract: Regarding the aspects of climate policy, the building sector in Hungary is one of the best performing industries. This means that the GHGs (Greenhouse Gasses) the sector emits can be decreased more effectively and at less cost than in the case of other sectors. This is no surprise in the European Union, since there is a continual demand on behalf of society to develop old and outdated buildings, thus modern technological solutions also inherently result in operating efficacy. The 'climate policy targeted' development of the built environment based on EU funds is thus one of the most popular developments amongst European Union Member States. Therefore, the aim of the present study is to assess the climate policy effects of the presently preferred strategy approach(es) between 2020 and 2030.
\end{abstract}

Keywords: building renovation, climate innovation, national climate policy, EU ETS, green building sector, zero energy building

\section{INTRODUCTION}

The building sector is linked to climate policy by means of the GHG emissions of the energy use of the building stock in the domestic, institutional, and business sectors. From the aspect of environmental protection, it is in the exceptional situation that it is the focus of most national developments due to the immense and cost effective possibilities for reducing GHG emissions arising from the enormous mass of these buildings. The essence of the above is that since a given unit of investment can result in much greater reductions than in the other sectors definitive in climate change, the developments that aim at reducing GHG emissions are generally implemented in this sector (for example, transport) [1].

The sector's developments in the past decades have shown positive trends, which can be attributed to several quickly changing aspects. First and foremost, continuous developments in technology and the constant need on behalf of society manifest as a result in themselves already 
result in a fundamental improvement in efficacy [2]. In addition, outdated buildings passed their lifecycles in Central and Eastern European countries such as Hungary provide advantageous possibilities, since they are much cheaper to develop than systems operating with more developed technologies. However, in this case the issue arises that although they do enable the achievement of substantial results over the short term with the installation of simple heat insulation or replacing windows, these outdated systems cannot be further developed in a manner that ensures they reach the next stage of development. Thus, renovating an old prefabricated apartment building is obviously cheaper and more cost effective than doing the same with a modern passive house (with low GHG emissions), but the outdated heating systems used in the case of the former cannot be further developed, for instance to provide compliance with 'smart metering' [3].

The importance of this fact also has to be stressed because the modernization of the building stock is an issue important to the national economy. There are many people who criticize Hungary's present prefabricated housing renovation program (panel program), which follows the deep retrofit trend also popular in other parts of Europe [4]. The essence of the program in Western Europe is to provide new functions and rebuild the unused buildings found in city centers in Hungary, this process is concentrated on the renovation of the 40-50 year old prefabricated apartment buildings left over from the socialist era. Due to the lifecycle issues already deliberated above, more and more people are stressing the fact that new buildings should be built instead [5], although this requires a greater investment, such a program would be better suited for the long term and would provide a much better return [6].

Based on the above, the aim of our study is to review the present prefabricated housing renovation strategy by mapping the potential in developing the Hungarian building stock, and to then attempt to define the correct direction for the future in light of the results.

\section{MATERIALS AND METHODS}

The present study basically encompasses two periods. The first is the period between 2015 and 2020, for which we are already familiar with the regulative framework environment and valid measures. However, negotiations are still under way between the various Member States and European Union decision makers regarding the subsequent period of 2020-2030, which falls into the next EU program period. In order to develop this, it is necessary to be aware of the effects that the present trends can have on the meeting of the 2020 targets and how they contribute to the realization of climate policy targets. Despite the fact that forecasts show that the building sector is one of the best performing sectors regarding the reduction of GHG emissions [7], the rate of true potential does have to be assessed. This is required because unless those measures are defined that target the best utilization of available possibilities, the result could be severe losses in the area of overall welfare (even until 2020).

Since the main target of our study is the accurate mapping of present Hungarian building policy trends, the evaluation used studies that have previously already assessed these effects. Of these, the document entitled 'Employment Impacts of a Large-Scale Deep Building Energy Retrofit Programme in Hungary' [8] prepared by the Central European University was the first. It primarily emphasized labor market effects but also contains a significant amount of conclusions pertaining to GHG emission reductions and energy efficiency. 
The second is the Hungarian National Building Energy Strategy [9], which specifically deals with the long term issues of building energy.

A benchmarking analysis method was selected for the general evaluation of the building development scenarios between 2020 and 2030, as this method (which is fundamentally a level-comparison method) is the simplest for analyzing the temporal and spatial characteristics of the climate policy sector. In essence, it allows present and future development environments to be evaluated on the basis of the system of conditions developed by the authors and their assigned indices. The methodology is basically aimed at designating an optimal state (or best practice, as the case may be) to which the selected systems can then be fitted [10]. The procedure had to be specified for the purposes of the analysis to ensure that it can be interpreted for the analysis of climate policy processes. The scenarios described by Hungarian building strategies were made quantifiable, in accordance with the requirements of the European Union Climate Policy [11]:

- increasing the ratio of renewable energy sources in the sector,

- increasing energy efficiency, and

- decreasing $\mathrm{CO}_{2}$ emissions.

The studies analyzed the technological, environmental, and financial dimensions of the building sector along the lines of the above 3 main dimensions, assigning 3 indicators to each of the above dimensions. The study framework developed by the study are pictured in Tables 1,2 , and 3 .

\begin{tabular}{|c|c|c|c|c|}
\hline \multirow[t]{2}{*}{ Dimensions } & Code & $\begin{array}{l}\text { Status } \\
\text { indicators }\end{array}$ & Code & $\begin{array}{l}\text { Performance indicators (defining } \\
\text { the method of development) }\end{array}$ \\
\hline & \multicolumn{4}{|c|}{ ASPECTS OF THE RATIO OF RENEWABLE ENERGY } \\
\hline \multirow{3}{*}{ 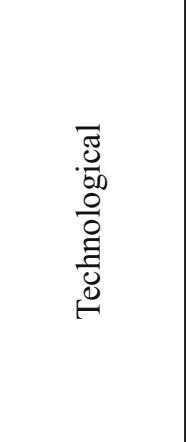 } & $\mathrm{RS} 1$ & $\begin{array}{l}\text { A specific study and the } \\
\text { general characteristics of } \\
\text { the applied energy mix }\end{array}$ & RP1 & $\begin{array}{l}\text { Changes in the use of expendable } \\
\text { resources: the increase or decrease } \\
\text { in the ratio of fossil energy } \\
\text { source usage in the examined } \\
\text { sector between } 2020 \text { and } 2030\end{array}$ \\
\hline & RS2 & $\begin{array}{l}\text { The general standard } \\
\text { and improvability of } \\
\text { technical equipment }\end{array}$ & $\mathrm{RP} 2$ & $\begin{array}{l}\text { The state of the technical standard } \\
\text { and the ratio of environmentally } \\
\text { friendly technologies }\end{array}$ \\
\hline & $\mathrm{RS} 3$ & $\begin{array}{l}\text { The ratio and characteristics } \\
\text { of renewable energy } \\
\text { source utilization }\end{array}$ & RP3 & $\begin{array}{l}\text { The possibilities for utilizing } \\
\text { renewable energy sources in the } \\
\text { sector and the possibilities for } \\
\text { increasing their rate within the sector }\end{array}$ \\
\hline \multirow{3}{*}{ 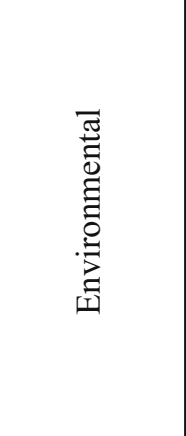 } & RS4 & $\begin{array}{l}\text { The characteristics of } \\
\text { participation in a waste } \\
\text { energy reuse system }\end{array}$ & RP4 & $\begin{array}{l}\text { Renewable energy system support, } \\
\text { classified according to roles }\end{array}$ \\
\hline & RS5 & $\begin{array}{l}\text { Results/relations between } \\
\text { emissions/imissions } \\
\text { benchmarks }\end{array}$ & RP5 & $\begin{array}{l}\text { Ratio of the potential for decreasing } \\
\text { emissions levels as compared } \\
\text { to the other ESD sectors }\end{array}$ \\
\hline & RS6 & $\begin{array}{l}\text { The rate/level of } \\
\text { environmental management } \\
\text { and the general sectoral } \\
\text { attributes of environmental } \\
\text { management systems }\end{array}$ & RP6 & $\begin{array}{l}\text { The effects of the EPC (Energy } \\
\text { Performance Certificate) on } \\
\text { the outlook for reduction } \\
\text { in the building sector }\end{array}$ \\
\hline
\end{tabular}




\begin{tabular}{|l|l|c|l|l|}
\hline & RS7 & $\begin{array}{c}\text { To what extent does the ratio } \\
\text { of the sector within the ESD } \\
\text { influence the country's position } \\
\text { on the quota market (AEA) }\end{array}$ & RP7 & $\begin{array}{c}\text { Evaluation of activity (characteristics } \\
\text { of carbon financing) }\end{array}$ \\
\cline { 2 - 5 } & RS8 & $\begin{array}{c}\text { The intensity/activity of } \\
\text { environmental policy and } \\
\text { climate policy regulation }\end{array}$ & RP8 & The effects of regulation on emissions \\
\cline { 2 - 5 } & RS9 & $\begin{array}{c}\text { Resource efficiency } \\
\text { complexity: labor market } \\
\text { effects and effects } \\
\text { on employment }\end{array}$ & RP9 & $\begin{array}{c}\text { Study of job creation effects and } \\
\text { the description of its significance }\end{array}$ \\
\hline
\end{tabular}

Table 1. Indicator group 1 of the building sector benchmarking analysis

Abbreviations: 'RS1 - 9:' status indicators of the ratio of renewable energy, according to dimensions; 'RP1 - 9:' performance indicators of the ratio of renewable energy, according to dimensions

As also made apparent by Table 1, the specific renewable indicators created by the study can be classified into two groups: Renewable Status Indicators (RS 1-9) and Renewable Performance Indicators (RP 1-9). The essence of developing Status Indicators is to define points within the sector whose change could be important regarding the sector's future climate policy development possibilities. However, this is a static index that primarily sheds light on the areas that might require change. The performance indicator group provides an answer to the question of how the intervention should take place. Thus, the Performance Indicators basically make it possible to define the direction and possible degree of the changes to the processes shown by the Status Indicators.

As mentioned earlier, the two important periods of the study are that between 2010 and 2020 and that between 2020 and 2030. This differentiation was primarily necessary because analyzing the processes that take place between 2020 and 2030 would not have provided a suitable direction, as there would have been no comparison for the hypotheses (which can be subsequently corrected in light of possible changes).

The analyses for the 2010-2020 period make the types of problems that can arise in planning in the case of long term planning apparent. The main conclusion of the analysis was that reviews of the defined 10 year plans conducted at least every 5 years are unavoidable if the correct development courses are to be adhered to.

The study therefore compared the expected results of the Hungarian building renovation programs and building energy strategy with the climate targets set for 2020 and 2030, respectively. Estimates made by experts in the field were then used to determine whether they are suitable for achieving these goals. The indicators included in the tables fundamentally aim at enabling the localization of the degree of externalities (not monetized effects) compounded in the sector $[12,13]$. 


\begin{tabular}{|c|c|c|c|c|}
\hline \multirow[t]{2}{*}{ Dimensions } & Code & $\begin{array}{l}\text { Status } \\
\text { indicators }\end{array}$ & Code & $\begin{array}{l}\text { Performance indicators (defining } \\
\text { the method of development) }\end{array}$ \\
\hline & \multicolumn{4}{|c|}{ ASPECTS FOR INCREASING ENERGY EFFICIENCY } \\
\hline \multirow{3}{*}{ 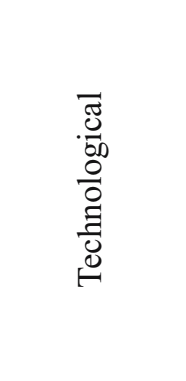 } & ES1 & $\begin{array}{l}\text { The ratio of electrical } \\
\text { energy use in total } \\
\text { energy use }\end{array}$ & EP1 & $\begin{array}{l}\text { The ratio of electrical energy } \\
\text { used by the building sector }\end{array}$ \\
\hline & ES2 & $\begin{array}{l}\text { The degree of } \\
\text { consumption of } \\
\text { ETS sectors }\end{array}$ & EP2 & Share of district heating \\
\hline & ES3 & $\begin{array}{l}\text { The degree/rate of } \\
\text { possible clean tech } \\
\text { applications }\end{array}$ & EP3 & $\begin{array}{l}\text { The application of clean tech in } \\
\text { only the renovated building stock } \\
\text { (excluding new buildings) }\end{array}$ \\
\hline \multirow{3}{*}{ 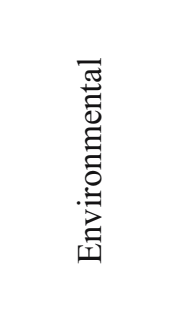 } & ES4 & $\begin{array}{l}\text { The intensity of } \\
\text { input utilization } \\
\text { within the sector }\end{array}$ & EP4 & Building sector energy use \\
\hline & ES5 & $\begin{array}{l}\text { Optimization level } \\
\text { of building }\end{array}$ & EP5 & $\begin{array}{l}\text { Ratio of zero energy buildings and } \\
\text { buildings that use energy effectively }\end{array}$ \\
\hline & ES6 & Level of energy loss & EP6 & Decrease of dependency on energy imports \\
\hline \multirow{3}{*}{ 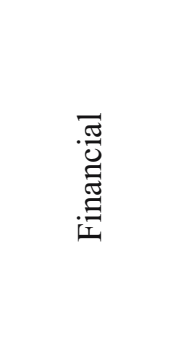 } & ES7 & $\begin{array}{l}\text { Cost effectiveness } \\
\text { parameters of increasing } \\
\text { energy efficiency }\end{array}$ & EP7 & $\begin{array}{l}\text { Ratio of cost effective } \\
\text { potential for reduction }\end{array}$ \\
\hline & ES8 & $\begin{array}{l}\text { Characteristics of } \\
\text { increases in eco-efficiency }\end{array}$ & EP8 & Rates of investments/savings \\
\hline & ES9 & $\begin{array}{l}\text { The significance of } \\
\text { regulatory elements in } \\
\text { production processes }\end{array}$ & EP9 & $\begin{array}{l}\text { Change in the reduction } \\
\text { resulting from regulation }\end{array}$ \\
\hline
\end{tabular}

Table 2. Indicator group 2 of the building sector benchmarking analysis

Abbreviations: 'ES 1 - 9:' status indicators of the energy efficiency aspect, according to dimensions;

'EP 1 - 9:' performance indicators of the energy efficiency aspect, according to dimensions

\begin{tabular}{|c|c|c|c|c|}
\hline \multirow{2}{*}{ Dimensions } & Code & \multicolumn{1}{c|}{$\begin{array}{c}\text { Status } \\
\text { indicators }\end{array}$} & Code & $\begin{array}{c}\text { Performance indicators (defining } \\
\text { the method of development) }\end{array}$ \\
\cline { 2 - 6 } & THE ASPECTS OF CO & REDUCTION LEVELS \\
\hline \multirow{3}{*}{ CS1 } & $\begin{array}{c}\text { The intensity of GHG } \\
\text { emissions in light of the } \\
\text { given technology }\end{array}$ & $\mathrm{CP} 1$ & \multicolumn{2}{|c|}{$\begin{array}{c}\text { GHG emissions based on the } \\
\text { evaluation of the available } \\
\text { technical variants }\end{array}$} \\
\cline { 2 - 6 } & $\mathrm{CS} 2$ & $\begin{array}{c}\text { The possibility of } \\
\text { introducing low-carbon } \\
\text { technologies to the sector }\end{array}$ & $\mathrm{CP} 2$ & $\begin{array}{c}\text { The ratio of applicability of } \\
\text { available low-carbon technologies }\end{array}$ \\
\cline { 2 - 6 } & $\mathrm{CS} 3$ & $\begin{array}{c}\text { Composition/volume index } \\
\text { of characteristic GHGs }\end{array}$ & $\mathrm{CP} 3$ & Changes in CO2 reduction rates \\
\hline
\end{tabular}




\begin{tabular}{|c|c|c|c|c|}
\hline \multirow{3}{*}{ 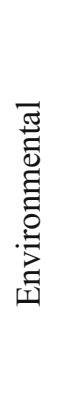 } & CS4 & $\begin{array}{c}\text { Environmental characteristics } \\
\text { of GHG emissions }\end{array}$ & $\mathrm{CP} 4$ & $\begin{array}{l}\text { Description of GHG environmental } \\
\text { characteristics and their } \\
\text { evaluation from the aspect } \\
\text { of the expected measures }\end{array}$ \\
\hline & CS5 & $\begin{array}{l}\text { Environmental regulations/ } \\
\text { norms, thresholds/consistency }\end{array}$ & $\mathrm{CP} 5$ & $\begin{array}{l}\text { Do regulations support } \\
\text { or hinder the meeting of } \\
\text { environmental policy targets }\end{array}$ \\
\hline & CS6 & $\begin{array}{l}\text { The level of environmental } \\
\text { risks in emissions }\end{array}$ & CP6 & $\begin{array}{c}\text { The characteristics and nature } \\
\text { of adaptation measures }\end{array}$ \\
\hline \multirow{3}{*}{$\begin{array}{l}. \bar{\pi} \\
\stackrel{\Xi}{\Xi} \\
.\end{array}$} & CS7 & $\begin{array}{c}\text { The characteristics/level } \\
\text { of participation in total } \\
\text { GHG emissions }\end{array}$ & $\mathrm{CP} 7$ & $\begin{array}{l}\text { The ratio of total } \mathrm{CO} 2 \text { emissions in } \\
\text { all sectors subject to the regulation }\end{array}$ \\
\hline & CS8 & $\begin{array}{l}\text { Typical costs of } \mathrm{GHG} \\
\text { reduction per unit of } \mathrm{CO}_{2 \mathrm{e}}\end{array}$ & $\mathrm{CP} 8$ & $\begin{array}{l}\mathrm{CO}_{2} \mathrm{e} \text { reduction cost index } \\
\text { in the examined sector }\end{array}$ \\
\hline & CS9 & $\begin{array}{l}\text { The nature of the contribution } \\
\text { to the meeting of GHG } \\
\text { climate policy targets }\end{array}$ & CP9 & Volume and efficiency calculations \\
\hline
\end{tabular}

Table 3. Indicator group 3 of the building sector benchmarking analysis

Abbreviations: 'CS 1 - 9:' status indicators of the aspect of reducing $\mathrm{CO}_{2}$ emissions, according to dimensions; 'CP 1 - 9:' performance indicators of the aspect of reducing $\mathrm{CO}_{2}$ emissions, according to dimensions

\subsection{Interpreting externalities in climate policy research}

During the course of the present study, the term externalities was not used as customary in traditional economic analyses (as a specific index of the rate of environmental problems) but rather as a complex system of measurement that influences the success of the development. The externalities taken into consideration by the study include the manifestation of all those positive and negative environmental, economic, and social features that influence the development of or the ability to develop the local building sector but that are generally not taken into account by decision makers [14]. These externalities were identified by stressing the contradictions experienced on the market and the factors that arise during developments and support or possibly hinder those. The evaluation framework developed by the authors therefore primarily dealt with the degree to which a given indicator contributes to the achievement of climate policy targets within a sector. Each of the 9 indicators of the three evaluation system categories illustrated in Tables 1, 2, and 3 (financial, environmental, and technological) were allocated a value $[(-2),(-1),(0),(1),(2)]$ depending on whether they over-performed or under-performed according to the reviewed index. It should be stressed that although the accumulation of positive externalities naturally assumes a more beneficial state than the accumulation of negative factors (since it indicates a structure that is at least worthy of continued development), that is not the optimal level of balance. The optimal level of these systems (best practice) is always indicated by 0 , meaning that the most beneficial system is that which has a value close to 0 . 
The accumulation of negative factors denotes a structure that is fundamentally faulty in its operation and into which financial sources should not be invested, as they will not provide a return over the long term (within their respective lifecycles). Contrarily, the accumulation of positive externalities always means that there is untapped potential present. As a result, that is the direction investments should take to ensure these possibilities are not left unused [15].

\section{RESULTS}

The result of the benchmarking study makes it unequivocal which obstacles to using resources or best practices we can encounter in the three dimensions (technological, environmental, financial) of the studied areas. The detailed results of the benchmarking study are summarized in Table 4 . The table highlights 3 factors that were each separately considered important in the interest of a comprehensive analysis. Of these, the first ('Net positive externalities'), indicated with a letter ' $A$,' is the mathematical sum of the externalities. The value denoted as ' $B$ ' ('Total externalities $A B S^{\prime}$ ) is the absolute value of the number of externalities in the given sector. Finally, index ' $C$ ' provides a sum of the ratio of net positive externalities (A) within the total number of externalities (B). The technological dimension included the study of changes to the technological state, while the environmental dimension dealt with the effects that the various regulations or measures can have on the sector. Finally, the financial dimension tracked the effect of the various types of support available for developing buildings.

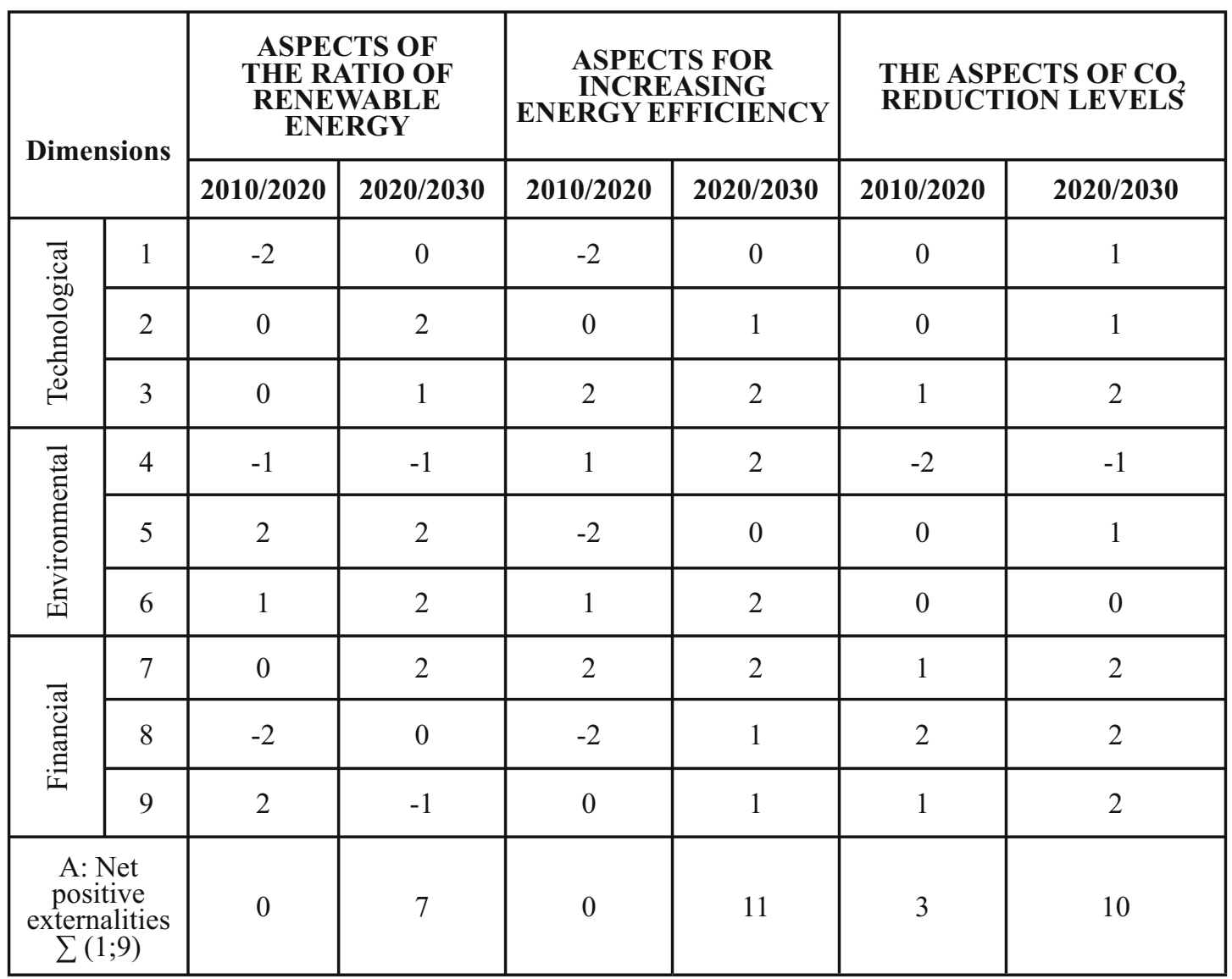




\begin{tabular}{|c|c|c|c|c|c|c|}
\hline $\begin{array}{c}\text { B: Total } \\
\text { externalities } \\
\text { ABS (1;9) }\end{array}$ & 10 & 11 & 12 & 11 & 7 & 13 \\
\hline $\begin{array}{c}\text { C: } \text { The } \\
\text { ratio of net } \\
\text { positive } \\
\text { external } \\
\text { effects } \\
\text { within total } \\
\text { external } \\
\text { effects }\end{array}$ & $0 \%$ & $64 \%$ & $0 \%$ & $100 \%$ & $43 \%$ & $77 \%$ \\
\hline
\end{tabular}

Table 4. Evaluation of the building sector benchmarking analysis

Explanation: A: Net positive externalities $\sum(1 ; 9)$ : the number of positive externalities within the various aspects in 2020 and 2030, respectively, if no directed climate policy developments take place outside of BAU; B: Total externalities ABS $(1 ; 9)$ : the absolute value of the total number of externalities; C: The ratio of net positive external effects within total external effects; expressed as a percentage, it indicates the dimension of improvability in the studied area.

In general, it can be stated that the results of the benchmarking study shows that the building sector does not generate a substantial amount of externalities in the 2010-2020 period, as a result of which it does not require any substantial measures targeting emissions reductions. The aspect of $\mathrm{CO}_{2}$ reduction, a critical development factor, is an exception, since the European Union designated this factor as a main priority, with international climate targets (Kyoto Protocol) focusing mainly on reducing GHG emissions. Thus, it is interesting that these two sub-systems (renewable energy and energy efficiency), which decision makers believe should create a balance in the $\mathrm{CO}_{2}$ equation through harmonious operations, still fail to fulfil this function. The reason is that the national commitments for 2020 fail to meet the levels of possible commitments, allowing countries to fulfil their EU targets without conducting any significant developments in the sector [16]. The positive externalities apparent in the $\mathrm{CO}_{2}$ aspect call attention to the fact that the sector contains significant potentials for speeding up low carbon developments, which however cannot be implemented without increasing voluntary GHG reduction commitments. (Note: It is public knowledge that Hungary, contrary to other EU Member States, did not make any additional commitments for GHG reductions for 2020.)

The 2020-2030 period shows a completely different overall picture. The details of Table 4 have to be studied to provide an accurate analysis of this fact. It becomes apparent that the rate of externalities in the sector (Index $B$ ) does not show any significant changes in either of the three main categories and merely shows a tendency to have positive values (Index $A$ ). This shows that after the 2020 target is met, the sector will have a vast amount of untapped potential by 2030 resulting from technological developments. At the beginning of the methodology part, it was noted that such effects are generally a result of failing to implement developments or measures in the present that would be the driving force for technological developments [17]. These missed opportunities can result in serious deadweight for society over the long term [18]. In the case of Hungary and the countries of the former Soviet bloc, the reason for this is primarily the preference of the prefabricated housing renovation trend instead of building new homes and public buildings. However, the detailed study broken down according to research aspects should also be taken into account to get a clearer picture. 


\subsection{Evaluation of research aspects}

The aspects of the renewable energy ratio: the technological characteristics group proved to be the most important dimension in this aspect: in it, the accumulation of externalities moved by a value of 5 in the positive direction (the total externality accumulation of the aspect in 2030 is illustrated in Figure 1.). This obviously does not come as a great surprise in light of the fact that political decision makers prefer expanding the present system of nuclear energy, which in theory can provide cheap electricity to homes as well. As a result, many developments will be foregone over the long term that would push the building sector in the direction of utilizing renewable energy sources. However, the stance that Hungary has committed itself to developing Nearly Zero-Energy Buildings (hereinafter: NZEB), which, similarly to passive houses, use only very low levels of energy (and thus have low GHG emissions) seems contradictory. Another feature of NZEBs is that the little energy that they do require are provided by renewable energy sources. Hungary has come to an agreement with the EU that it will build only NZEBs after 2020, the performance of which commitment seems rather unlikely.

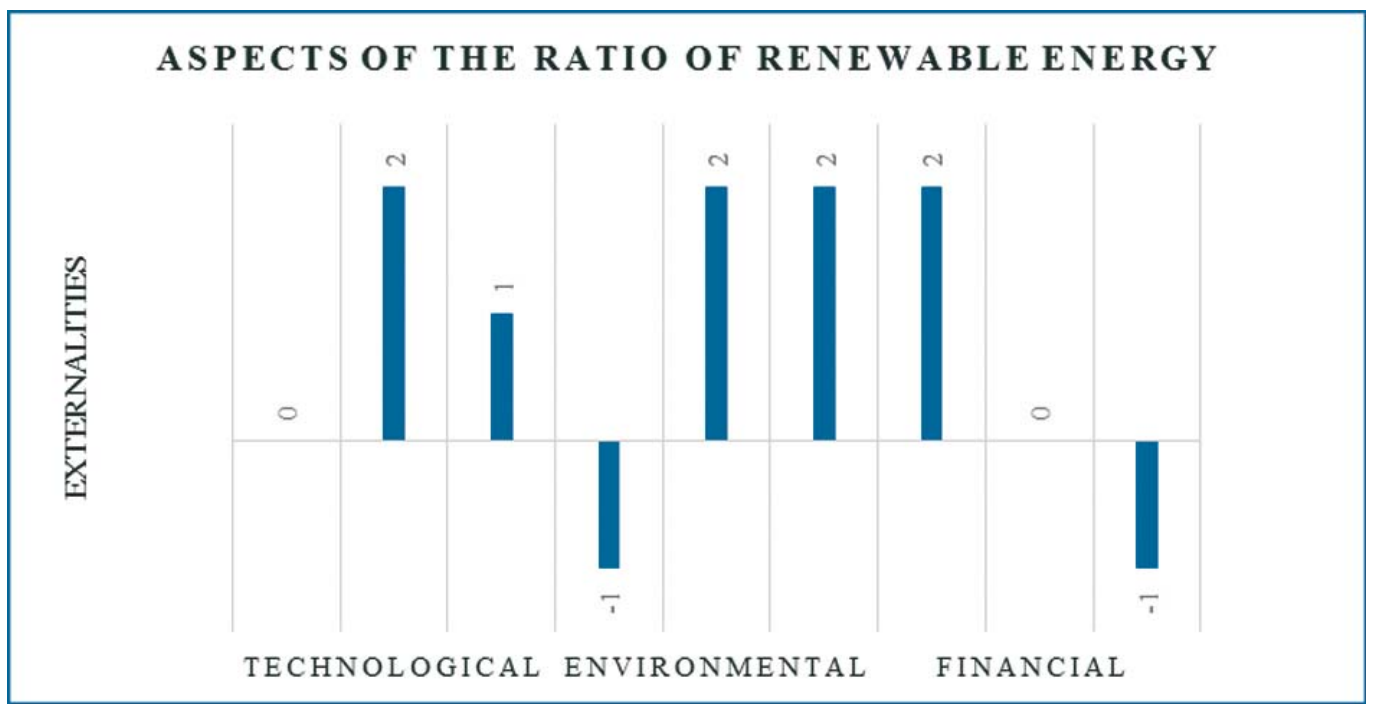

Figure 1. The number of externalities within the renewable energy aspect in 2030

The aspects of increasing energy efficiency: this aspect basically deals with an area where the failure to utilize available potential is not surprising. The reason is that in 2015 , the economic policy legislators declared that Hungary will not be spending significant amounts on increasing energy efficiency, since the country can meet the European Union's targets for 2020 without taking any serious measures.

Table 4 shows that the two most important dimensions were the environmental and the financial dimensions, where the accumulation of positive externalities jumped by a value of 4 from one period to the next. As a result of this change Figure 2 shows the high level of externality aggregation regarding the two mentioned dimensions in 2030 . This therefore indicates that the absence of regulation and support (financing) targeting increased efficiency end up squandering long term possibilities that would be easy to make use of in the present but will be difficult in the future $[19,20]$. In summary, there is a contradiction between the realization 
of the set goals and the preparations required for doing so, as the construction of the NZEBs mentioned above requires serious planning and resource allocation. However, the present political stance (which prefers nuclear developments) does not seem to indicate support becoming available for building low-carbon buildings.

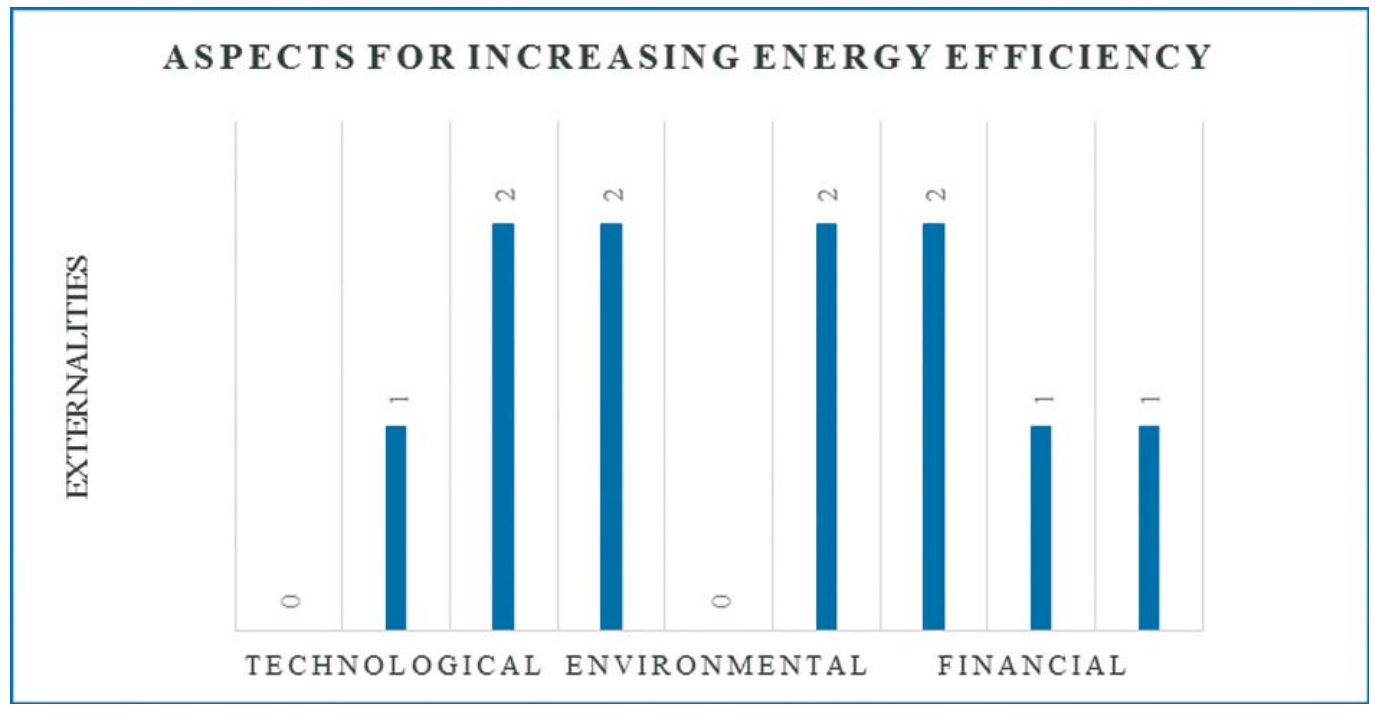

Figure 2. The externality aggregation of the energy efficiency aspects in 2030

The aspects of $\mathrm{CO}_{2}$ reduction: the last aspect shows the greatest ratio of change in externalities. According to the results presented by Table 4, the value of externalities will increase from 7 in the 2010-2020 period to 13 by 2030. Similarly to renewable energy sources, the greatest change in externalities between the two periods takes place in the technological dimension. This indicator unequivocally shows that developments in technological conditions can pose a serious obstacle in the sustainable development and operation of the building sector. The tendency towards the optimal value is apparent in the case of the environmental dimensions, leading to the conclusion that there is no need for a substantial rethink of sectoral regulations until either 2020 or 2030. The detailed benchmarking analysis also justified this result, as, based on the performed studies, it led to the conclusion that the mandatory EU regulations fundamentally determine all the conditions that, if kept, ensure that climate policy targets can be met.

The bigger problem is the performance of economic conditions or costs: the utilization of support funds. In this field, it can be seen that several developments would be implemented in the 2010-2020 period that would require larger amounts of development funds, but still might not be performed (for example, the development of a smart metering system). By 2030, this deficit in development will only grow, which unequivocally shows that although there are possibilities available for reducing GHG emissions over the long term, the allocation of funds is still necessary in order to provide for their utilization (Figure 3). 


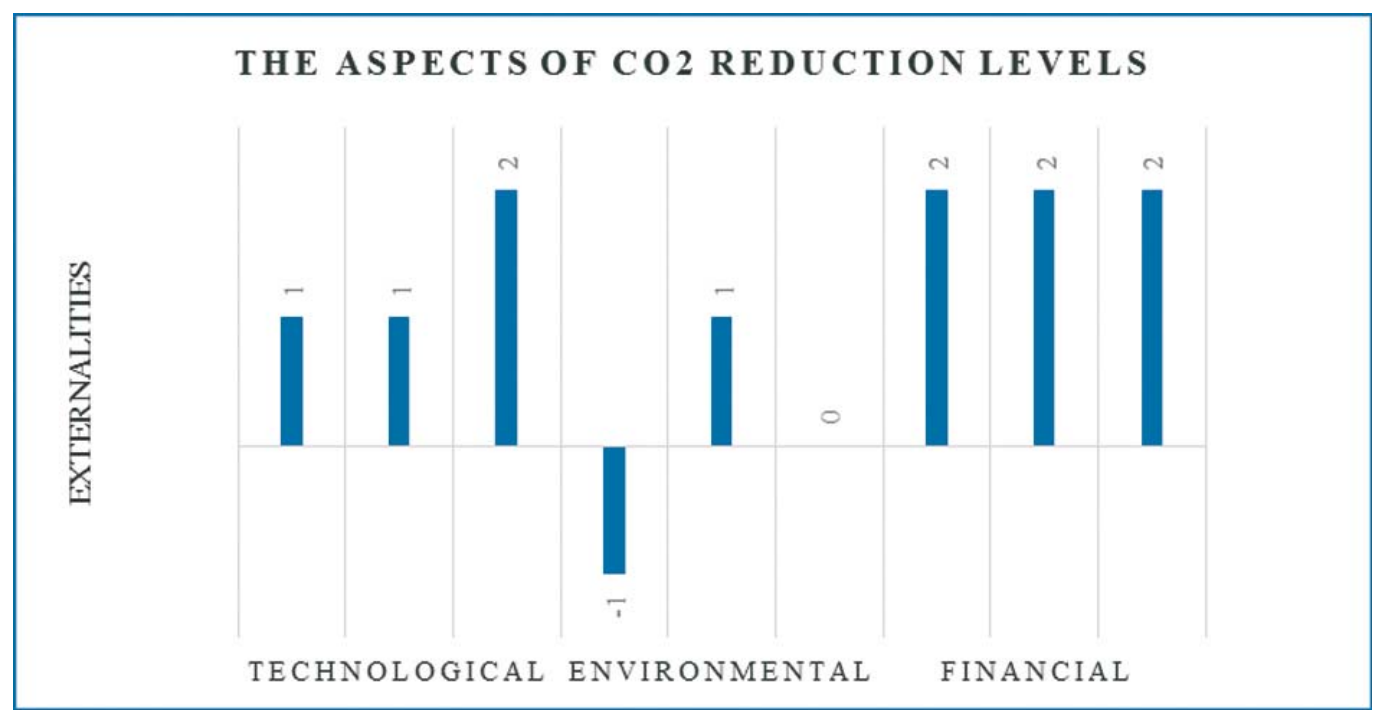

It is important to stress that the full internalizing of positive externalities (maximally using available possibilities) would presumably result in over-performance in the sector in the climate policy area; as a result, the industry would have no trouble attaining climate policy goals and in fact could even undertake additional commitments.

Regardless, the present processes also indicate that potentials will not be suitably utilized, which could result in deadweight for citizens [21].

The reason behind this is that there are several sectors within climate policy (for example, transport and agriculture) that do not necessarily have such possibilities for development, and so their negative characteristics would have to be offset by the better performing sectors. It is thus safe to say that good performance cannot be overdone in the building sector, since achieving the maximum performance is necessary for all industries.

\section{CONCLUSION}

The fundamental aim of the present study was to assess how the building sector can contribute to Hungary's meeting of climate policy targets set by the European Union. The study mainly focused on one issue: that of modernizing the building stock. According to the trends that are presently preferred, this process is to take place with the renovation of old buildings. However, several experts declare that this approach can result in grievous financial, social, and environmental losses over the long term. The authors feel that the construction of new buildings in place of the old ones would be more expedient than the use of the present general prefabricated apartment building renovation programs, as the old buildings are at the end of (or, in many cases, past) their lifecycles; in addition, there is practically no financial benefit in these types of investments. An accurate cost-benefit analysis that deals with the financial return of these two possibilities and their environmental and social effects is required to assess this issue in the future.

The relations that can be established on the basis of the benchmarking studies provide a good indication of which areas the cost-benefit analyses should concentrate on as well as which 
are the vulnerable and sensitive points in the system's long term development.

First of all, it becomes apparent that although the present trends do indeed guarantee optimal operations for the sector until 2020, the 2020-2030 period will have significant amounts of untapped development potential. In the field of energy efficiency, it can be seen that the lack of compulsory performance has resulted in central source-based support for energy efficiency programs not even being included in economic policy plans. Although the reason for this is clear (the present study also proves that Hungary will still meet the EU's climate policy targets), the country ends up holding the sector's development possibilities back and slowing the rate of modernization. According to the results of the study, the renewable energy developments taking place in the building sector are significantly limited by the nuclear energy program. In addition, the program bases the energy use of buildings after 2025 not on self-sufficiency, but on the electrical energy generated by nuclear power plants.

There are a number of contradictions between the previously undertaken European Union commitments and present financial preferences. The meeting of the Nearly Zero-Energy Building commitments for the post-2020 period is utterly impossible with the present building development concepts. Accurate cost-benefit analyses are necessary to obtain a clear picture of the positive and negative characteristics of the various development alternatives, of the nature of the possible developments for the 2020-2030 period, and of the possibilities for utilizing climate funding (totaling several billion HUF). The resource characteristics that describe a sector's general performance and that were defined in the above benchmarking studies could form an excellent basis for the cost-benefit analyses.

\section{ACKNOWLEDGMENTS}

This work was supported by Szent Istvan University Climate Change Economic Research Centre. 


\section{REFERENCES}

[1] Borkent, B., O’Keeffe, S., Neelis, M., Gilbert, A., Costs and Effectiveness of Domestic Offset Schemes, Final report. Ecofys, London, 2012. URL: http://www.ecofys.com/files/files/ecofys-2012-cost-and-effectiveness-of-domestic-offsetschemes.pdf

[2] Forster, D., Okamura, S., Wilkins, G., Morris, M., Scott, P., Kuikman, P., Lesschen, J., P., Gardiner, A., Boermans, T., Grözinger, J., Eichнammer, W., Reichardt, K. (2012): Next phase of the European Climate Change Programme: Analysis of Member States actions to implement the Effort Sharing Decision and options for further community-wide measures. AEA group, Harwell, 2012. URL: http://ec.europa.eu/clima/policies/effort/docs/esd_final_report_en.pdf

[3] Bastos, J., Batterman, B. S., Freire, F. Life-cycle energy and greenhouse gas analysis of three building types in a residential area in Lisbon. Energy and Buildings, Volume 69 (2014), pp. 344-353. DOI: 10.1016/j.enbuild.2013.11.010

[4] Arcipowska, A., Anagnostopoulos, F., Mariottini, F., Kunkel, S., Energy Performance Certificates Across The EU - A Mapping of National Approaches. Buildings Performace Institute Europe (BPIE). Brussels, 2014. URL: http://bpie. eu/uploads/lib/document/attachment/81/BPIE_Energy_Performance_Certificates_EU_mapping_-_2014.pdf

[5] Lovell, H., Framing sustainable housing as a solution to climate change. Journal of Environmental Policy \& Planning, Volume 6 (2004), Issue 1, pp. 35-55. DOI: 10.1080/1523908042000259677

[6] Nadoushani, Z., S., M., Akbarnezhad, A., Effects of structural system on the life cycle carbon footprint of buildings. Energy Buildings, Volume 102 (2015), pp. 337-346. DOI: 10.1016/j.enbuild.2015.05.044

[7] Leduc, G., Blomen, E., Sectoral Emission Reduction Potentials and Economic Costs for Climate Change (SERPECCC), Transport - Passenger cars, road freight and aviation. Ecofys, London, 2009. URL: http://www.ecofys.com/files/ files/serpec transport_report.pdf

[8] Vorsatz, Ü., D., Arena, D., Herrero, T., S., Butcher, A., Telegdy, Á., Fegyverneky, S., Csoknyai, T., KöPataki, É., Jankó, A., Employment Impacts of a Large-Scale Deep Building Energy Retrofit Programme in Hungary for 3CSEP and European Climate Foundation, Central European University, Budapest, 2010. URL: http://zbr.kormany.hu/ download/8/82/00000/Study\%20Deep\%20Building\%20Energy\%20Retrofit\%20Prog.pdf

[9] NFM., Nemzeti Épületenergetikai Stratégia, Nemzeti Fejlesztési Minisztérium, Budapest, 2015.

URL: http://www.kormany.hu/download/d/85/40000/Nemzeti\%20E\%CC\%81 pu\%CC\%88letenergetikai\%20Strate $\%$ CC\%81gia\%20150225.pdf

[10] Camp, R., C. 'Learning from the Best Leads to Superior Performance', Journal of Business Strategy, Volume 13 (1992) Iss: 3, pp. 3 - 6 DOI: 10.1108/eb039486

[11] Fogarassy, Cs., Bakosne, B., M., Lukács a. A széndioxid-emissziókereskedelem. Agrofórum: a növényvédők és növénytermesztök havilapja. Vol. 22. No. 10. (2011) 82-83. p., ISSN: 1788-5884 URL: http://regihonlap.agroforum. hu/archivum/agroforum-2011-oktober

[12] Fogarassy, C., Bakosne, B., M., Externality analysis of sustainable cattle breeding systems. Hungarian Agricultural Engineering Volume 26 (2014) pp. 5-10. DOI: 10.17676/HAE.2014.26.5

[13] Pigou, A. C., The Economics of Welfare, MacMillan, Part II. (1920) pp. 3334. URL: http://files.libertyfund.org/files/1410/Pigou_0316.pdf

[14] Farkas, F. M., Fogarassy, C., szucs, I. Allowance for external effects in efficiency calculations. In: Edited by Szucs. I. Fekete. F. M. - Efficiency in the agriculture (Theory in practice) Agroinform Publisher, Budapest, 2008 p. 114-122 ISBN 978-963-502-899-3

[15] Fogarassy, Cs., Karbongazdaság (low-carbon economy). Monográfia. L'Harmattan Kiadó, Budapest, 2012, ISBN: 978963-236-541-1 p. 262 URL: http://www.harmattan.hu/konyv_972.html

[16] Kuinckenberg, F., Pirie, F., M., Mcandrew, L., Renovation Roadmaps for Buildings. Report by The Policy Partners for Eurima, London, 2013. URL: http://www.eurima.org/uploads/ModuleXtender/Publications/96/Renovation_Roadmaps for Buildings PP FINAL Report 20 02 2013.pdf

[17] Schimschar, S., Hermelink, A., John, A., ZEBRA 2020 - Nearly Zero-Energy Building Strategy 2020, Deliverable D2.2: Tracking the market maturity for nZEB. Vienna University of Technology Energy Economics Group - EEG, Vienna, 2014. URL: http://zebra2020.eu/website/wp-content/uploads/2014/08/ZEBRA2020-Deliverable-D21_final.pdf

[18] Rysanek, A. M., Choudhary, R., Optimum building energy retrofits under technical and economic uncertainty. Energy and Buildings, Volume 57 (2013), pp. 324-337. DOI: 10.1016/j.enbuild.2012.10.027

[19] Huang, B., Yang, H., Mauerhofer, V., Sustainability assessment of low carbon technologies - case study of the building sector in China. Journal of Cleaner Production, Volume 32 (2012), pp. 244-250. DOI: 10.1016/j.jclepro.2012.03.031

[20] Hong, T., Ji, C., JANG, M., Park, H., 'Assessment Model for Energy Consumption and Greenhouse Gas Emissions during Building Construction. 'J. Manage. Eng., 30 Volume 2 (2014), pp. 226-235. DOI: 10.1061/(ASCE)ME.19435479.0000199

[21] Fogarassy, Cs., Bakosne, B., M., Rashad, S., M., Zsarnoczai, J., M. Low-carbon principles and sustainability relations of the Rubik's cube layer by layer solution method. Journal of Central European Green Innovation, Volume 2 Issue 4 (2014), pp. 29-52. URL: http://real.mtak.hu/23444/1/Fogarassy_et_al_3_u.pdf 